\title{
Numerical Classification of Slowly Growing Mycobacteria
}

\author{
M. TSUKAMURA \\ National Chubu Hospital, Obu, Aichi, Japan
}

\begin{abstract}
A total of 138 strains of slowly growing mycobacteria, which were received as members of 18 named species, were classified by scoring matching coefficients. Eighty-eight characters were tested for each strain; of these, 48 were useful for differentiating between strains. Mycobacterium tuberculosis and $M$. bovis were clearly separated from the other species. $M$. kansasii, $M$. marinum, $M$. gastri, and $M$. shimoidei were regarded as species clearly distinct from each other and from other species in the genus. The other species studied formed a large cluster within which $M$. szulgai and $M$. simiae were distinct. The remaining species could be divided into two large subclusters, one consisting of $M$. asiaticum, $M$. avium, $M$. intracellulare, $M$. scrofulaceum, $M$. gordonae, and $M$. xenopi, and the other consisting of $M$. nonchromogenicum, $M$. terrae, $M$. novum, and $M$. triviale. Within the former cluster, $M$. gordonae was regarded as a distinct species, and $M$. asiaticum and $M$. xenopi as fairly distinct species. In contrast to these, $M$. avium, $M$. intracellulare, and $M$. scrofulaceum were not clearly differentiated from each other and appeared to belong to a single species, for which the name $M$. avium has priority. Within the latter cluster, $M$. triviale appeared to be fairly distinct from the others. $M$. nonchromogenicum, $M$. terrae, and $M$. novum could not be differentiated from each other, and they appear to belong to a single species, for which the name $M$. nonchromogenicum has priority.
\end{abstract}

The classification of slowly growing mycobacteria entails considerable difficulty, for the organisms show negative matches in many biochemical tests which are useful for differentiating between other microorganisms. Nevertheless, the numerical classification of these microorganisms has been carried out by Bojalil et al. (3), Tsukamura (33, 35, 42, 45), Tsukamura and Tsukamura (56), Bogdanescu and Racotta (2), Wayne (62), Tsukamura and Mizuno (46), Tsukamura et al. (51), and Kubica and Silcox (14). In addition, the numerical classification of a limited number of species of slowly growing mycobacteria was undertaken by Wayne (61), Wayne et al. (64), Tsukamura et al. (50), Tsukamura (41), Wayne et al. (63), Kubica et al. (15), and Meissner et al. (21).

Of the above-mentioned studies, only a few $(3,15,21,33,56,63)$ were carried out using an $n$ $\times n$ matrix prepared from large numbers of test strains. The studies by Wayne et al. (63), Meissner et al. (21), and Kubica et al. (15) analyzed one or two groups of Runyon (23). Only three studies $(3,33,56)$ covered most of the species of slowly growing mycobacteria available at the time. However, the study by Bojalil et al. (3) in 1962 employed 30 characters, and the studies by Tsukamura (33) and Tsukamura and Tsukamura (56) in 1966 used 94 and 43 characters, respectively, of which 40 to 50 were useful for differentiating between test strains. These studies were carried out 10 or more years ago. Thereafter, a number of tests were added as useful for differentiating between strains of slowly growing mycobacteria, and several new species were reported. It was considered desirable to make a new numerical analysis of these microorganisms, including representatives of newly described species and using a new set of tests.

\section{MATERIALS AND METHODS}

Bacterial strains. A total of 138 strains of slowly growing mycobacteria was employed in this study. The strains and their sources are listed in Table 1. Out of these, strains 24005, 24006, 24008, 24009, 24010 , and 24018 of Mycobacterium novum showed the same results in all tests. Accordingly, only the data from strain 24018 were included in the analysis. The number of strains used in the $n \times n$ matrix is, therefore, 133.

Tests. Tests useful for differentiating between slowly growing mycobacteria and rapidly growing ones are given in Table 2. Eighty-eight characters were employed in this study (Table 3 ). These include those useful for differentiating between strains of rapidly growing mycobacteria. The number of characters useful for differentiating between strains of slowly growing mycobacteria is 48 . These are as follows: no. 4,7 to 9,11 to $31,36,38,39,41,43$ to 45 , 47,50 to $52,61,64,66,72$ to $77,85,86$, and 88 .

Numerical analysis. The matching coefficient (M 
TABLE 1. Strains studied

\begin{tabular}{|c|c|c|}
\hline Specific name of strain as received & $\begin{array}{c}\text { Strain designa- } \\
\text { tion }\end{array}$ & Source ${ }^{a}$ \\
\hline Mycobacterium tuberculosis (18) & $\begin{array}{l}05001 \\
05002 \\
\mathrm{E} 7193\end{array}$ & $\begin{array}{l}\text { H37Rv; S. Ata } \\
\text { Aoyama-B; S. Ata } \\
\text { M. Tsukamura }\end{array}$ \\
\hline Mycobacterium bovis $(6)$ & $\begin{array}{l}06001 \\
06002\end{array}$ & $\begin{array}{l}\text { Ravenel; K. Shoji } \\
\text { Denken; K. Konno }\end{array}$ \\
\hline Mycobacterium kansasii (9) & $\begin{array}{l}07001 \\
07002 \\
07003 \\
07005 \\
07006 \\
07007 \\
07009 \\
07013 \\
\text { E5412 } \\
\mathrm{E} 5413 \\
\mathrm{E} 5414\end{array}$ & $\begin{array}{l}\text { Forbes84; K. Takeya; E. H. Runyon } \\
\text { BostrumD35; K. Takeya; E. H. Runyon } \\
\text { M. Tsukamura } \\
\text { M. Tsukamura } \\
\text { P1; K. Takeya; E. H. Runyon } \\
\text { P16; K. Takeya; E. H. Runyon } \\
\text { P21; K. Takeya; E. H. Runyon } \\
\text { M. Tsukamura } \\
\text { M. Tsukamura } \\
\text { M. Tsukamura } \\
\text { M. Tsukamura }\end{array}$ \\
\hline Mycobacterium marinum (1) & $\begin{array}{l}08002 \\
08003 \\
08010 \\
08011 \\
08012 \\
08014 \\
08015 \\
08017 \\
08018 \\
\text { E4328 } \\
\text { E4329 } \\
\text { E4330 } \\
\text { E4332 } \\
\text { E4333 }\end{array}$ & $\begin{array}{l}\text { B916; K. Konno } \\
\text { B913; K. Konno } \\
\text { ATCC 927; ATCC } \\
\text { SN1251; R. Bönicke } \\
\text { SN1253; R. Bönicke } \\
\text { SN1256; R. Bönicke } \\
\text { SN1301; R. Bönicke } \\
\text { SN1304; R. Bönicke } \\
\text { SN1305; R. Bönicke } \\
\text { ATCC 25034; ATCC } \\
\text { ATCC 25035; ATCC } \\
\text { ATCC 25036; ATCC } \\
\text { ATCC 15038; ATCC } \\
\text { ATCC 25039; ATCC }\end{array}$ \\
\hline $\begin{array}{l}\text { Mycobacterium scrofulaceum } \\
\quad(\text { M. marinum }[27])\end{array}$ & $\begin{array}{l}12003 \\
12320 \\
12321 \\
12322 \\
12340 \\
13003 \\
36001 \\
\text { E7325 }\end{array}$ & $\begin{array}{l}\text { M. Tsukamura } \\
\text { ATCC 19981; ATCC } \\
\text { ATCC 15078; ATCC } \\
\text { ATCC 15080; ATCC } \\
\text { ATCC 23429; ATCC } \\
\text { ATCC 19079; ATCC } \\
\text { ATCC 19275; ATCC } \\
\text { M. Tsukamura }\end{array}$ \\
\hline Mycobacterium xenopi (25) & $\begin{array}{l}28001 \\
28002 \\
28003 \\
28004\end{array}$ & $\begin{array}{l}\text { ATCC 19156; ATCC } \\
\text { ATCC 19276; ATCC } \\
\text { ATCC 19250; ATCC } \\
\text { ATCC } 19970 ; \text { ATCC }\end{array}$ \\
\hline Mycobacterium szulgai (20) & $\begin{array}{l}\text { SZ12001 } \\
\text { SZ12002 } \\
\text { SZ12003 } \\
\text { SZ12004 } \\
\text { E7145 } \\
\text { E7420 }\end{array}$ & $\begin{array}{l}\text { no. } 23428 \text {; J. Marks } \\
\text { no. } 25932 \text { (= NCTC 10831); J. Marks } \\
\text { no. } 26701 \text {; J. Marks } \\
\text { no. } 20886 \text { (= NCTC 10829); J. Marks } \\
\text { M. Tsukamura } \\
\text { M. Tsukamura }\end{array}$ \\
\hline Mycobacterium gordonae (3) & $\begin{array}{l}12016 \\
\text { T12109 } \\
\text { T12110 } \\
\text { T12177 } \\
\text { T12178 } \\
\text { T12179 } \\
\text { T12180 } \\
\text { T12355 } \\
\text { E6099 } \\
\text { E6100 } \\
\text { E6101 } \\
\text { E6102 }\end{array}$ & $\begin{array}{l}\text { M. Tsukamura } \\
\text { ATCC 14470; ATCC } \\
\text { ATCC 19277; ATCC } \\
\text { ATCC 23283; ATCC } \\
\text { ATCC 23284; ATCC } \\
\text { ATCC 23285; ATCC } \\
\text { ATCC 23286; ATCC } \\
\text { ATCC 23398; ATCC } \\
\text { M. Tsukamura } \\
\text { M. Tsukamura } \\
\text { M. Tsukamura } \\
\text { M. Tsukamura }\end{array}$ \\
\hline
\end{tabular}


TABLE 1-Continued

\begin{tabular}{|c|c|c|}
\hline Specific name of strain as received & $\begin{array}{l}\text { Strain designa- } \\
\text { tion }\end{array}$ & Source $^{a}$ \\
\hline Mycobacterium avium (8) & $\begin{array}{l}11016 \\
11017 \\
11018 \\
11019 \\
11020 \\
11021 \\
11022 \\
11023\end{array}$ & $\begin{array}{l}\text { ATCC 15769; ATCC } \\
\text { ATCC 19075; ATCC } \\
\text { ATCC 17941; ATCC } \\
\text { ATCC 17944; ATCC } \\
\text { ATCC 15773; ATCC } \\
\text { ATCC 17942; ATCC } \\
\text { ATCC 17939; ATCC } \\
\text { ATCC 17938; ATCC }\end{array}$ \\
\hline Mycobacterium intracellulare (24) & $\begin{array}{l}13082 \\
13085 \\
\text { E6052 } \\
\text { E6105 } \\
\text { E6106 } \\
\text { E6109 } \\
\text { E7123 } \\
\text { E7301 } \\
\text { E7302 } \\
\text { E7304 } \\
\text { E7306 } \\
\text { E7307 } \\
\text { E7309 } \\
\text { E7328 } \\
\text { E7365 } \\
\text { E7369 } \\
\text { E7371 } \\
\text { E7372 }\end{array}$ & $\begin{array}{l}\text { ATCC 19077; ATCC } \\
\text { ATCC 15985; ATCC } \\
\text { M. Tsukamura } \\
\text { M. Tsukamura } \\
\text { M. Tsukamura } \\
\text { M. Tsukamura } \\
\text { M. Tsukamura } \\
\text { M. Tsukamura } \\
\text { M. Tsukamura } \\
\text { M. Tsukamura } \\
\text { M. Tsukamura } \\
\text { M. Tsukamura } \\
\text { M. Tsukamura } \\
\text { M. Tsukamura } \\
\text { M. Tsukamura } \\
\text { M. Tsukamura } \\
\text { M. Tsukamura } \\
\text { M. Tsukamura }\end{array}$ \\
\hline Mycobacterium simiae (66) & $\begin{array}{l}\text { E7527 } \\
\text { E7528 } \\
\text { E7529 } \\
\text { E7530 } \\
\text { E7531 }\end{array}$ & $\begin{array}{l}\text { H. Saito; J. Weiszfeiler (no. 51) } \\
\text { H. Saito; J. Weiszfeiler (no. 53) } \\
\text { H. Saito; J. Weiszfeiler (no. 54) } \\
\text { H. Saito; J. Weiszfeiler (no. 55) } \\
\text { H. Saito; J. Weiszfeiler (no. 59) }\end{array}$ \\
\hline Mycobacterium asiaticum (67) & $\begin{array}{l}\text { E7523 } \\
\text { E7524 } \\
\text { E7525 } \\
\text { E7526 }\end{array}$ & $\begin{array}{l}\text { H. Saito; J. Weiszfeiler (no. 27) } \\
\text { H. Saito; J. Weiszfeiler (no. 32) } \\
\text { H. Saito; J. Weiszfeiler (no. 61) } \\
\text { H. Saito; J. Weiszfeiler (no. 64) }\end{array}$ \\
\hline Mycobacterium shimoidei $(52)$ & $\begin{array}{l}\text { Z7367 } \\
\text { E7367 } \\
\text { E7380 }\end{array}$ & $\begin{array}{l}\text { M. Tsukamura } \\
\text { M. Tsukamura } \\
\text { M. Tsukamura }\end{array}$ \\
\hline $\begin{array}{l}\text { Mycobacterium nonchromogenicum } \\
\quad(29)\end{array}$ & $\begin{array}{l}09003 \\
09013 \\
09015 \\
09016 \\
09017 \\
09020 \\
09023 \\
09033\end{array}$ & $\begin{array}{l}\text { ATCC 19530; M. Tsukamura (E 317) } \\
\text { ATCC 19531; M. Tsukamura (E1711) } \\
\text { M. Tsukamura (E1713) } \\
\text { M. Tsukamura (E1714) } \\
\text { M. Tsukamura (E1715) } \\
\text { M. Tsukamura (E1718) } \\
\text { ATCC 19532; M. Tsukamura (E1721) } \\
\text { ATCC 19533; M. Tsukamura (E1731) }\end{array}$ \\
\hline Mycobacterium terrae $(61)$ & $\begin{array}{l}38001 \\
38002 \\
38003 \\
38004 \\
38006 \\
38007 \\
38008 \\
38013 \\
38014\end{array}$ & $\begin{array}{l}\text { L. G. Wayne (W167) } \\
\text { L. G. Wayne (W168A) } \\
\text { L. G. Wayne (W171) } \\
\text { L. G. Wayne (W527) } \\
\text { L. G. Wayne (W897) } \\
\text { L. G. Wayne (W900) } \\
\text { L. G. Wayne (W923) } \\
\text { ATCC 15755; L. G. Wayne (W45) } \\
\text { L. G. Wayne (W511) }\end{array}$ \\
\hline
\end{tabular}


TABLE 1 -Continued

\begin{tabular}{lcl}
\hline Specific name of strain as received & $\begin{array}{c}\text { Strain designa- } \\
\text { tion }\end{array}$ & \multicolumn{1}{c}{ Source $^{a}$} \\
\hline Mycobacterium novum (36) & 24005 & M. Tsukamura \\
& 24006 & M. Tsukamura \\
& 24008 & M. Tsukamura \\
& 24009 & M. Tsukamura \\
& 24010 & M. Tsukamura \\
& 24013 & M. Tsukamura \\
Mycobacterium triviale (16) & 24018 & ATCC 19619 (= NCTC 10486); M. Tsukamura \\
& 24019 & ATCC 19620 (= NCTC 10496); M. Tsukamura \\
& 24032 & M. Tsukamura \\
& 37001 & \\
& 37002 & G. P. Kubica(alb2386) \\
& 37003 & G. P. Kubica (DT67-4) \\
& 37004 & G. P. Kubica (C1614) \\
Mycobacterium gastri (61) & 37005 & G. P. Kubica (C5181 = ATCC 19386) \\
& 37013 & G. P. Kubica (T20-5) \\
& G. P. Kubica (T254-3 = ATCC 19387) \\
& 25001 & L. G. Wayne (W417= ATCC 15754) \\
& 25002 & L. G. Wayne (W462) \\
& 25003 & L. G. Wayne (W465) \\
& 25004 & L. G. Wayne (W471) \\
& 25005 & L. G. Wayne (W479) \\
& 25006 & L. G. Wayne (W486) \\
& 25007 & L. G. Wayne (W487) \\
& 25008 & L. G. Wayne (W504) \\
\hline
\end{tabular}

a S. Ata, Nagoya University, Nagoya, Japan; K. Shoji, Osaka University, Osaka, Japan; K. Konno, Tohoku University, Sendai, Japan; K. Takeya, Kyushu University, Fukuoka, Japan; E. H. Runyon, Veterans Administration Hospital, Salt Lake City, Utah, U.S.A.; ATCC, American Type Culture Collection, Rockville, Maryland, U.S.A.; R. Bönicke, Forschungsinstitut Borstel, Borstel, West Germany; J. Marks, Tuberculosis Reference Laboratory, University Hospital of Wales, Cardiff, Great Britain; NCTC, National Collection of Type Cultures, Central Public Health Laboratory, London, England; H. Saito, Hiroshima University, Hiroshima, Japan; J. Weiszfeiler, Microbial Research Group, Hungarian Academy of Sciences, Budapest, Hungary; L. G. Wayne, Veterans Administration Hospital, Long Beach, California, U.S.A.

${ }^{b}$ These strains were identified in our laboratory.

value) between two strains was calculated by the following equation: $\mathrm{M}$ value $(\%)=\left(n_{s} \times 100 \%\right) /\left(n_{s}+\right.$ $n_{d}$ ), where $n_{s}$ is the number of characters that show similar code symbols $(++$ or --$)$ and $n_{d}$ is the number of characters which show different code symbols $(+-)$. The clustering was made by the single-linkage method (26).

The computer used was the NEAC 2200, model 250B, Nippon Electric Co., Tokyo, Japan, which is located in the Nagoya Factory, the Sumitomo Machinery Co., Obu, Aichi, Japan. The program number is G90001 of the Nagoya Factory, the Sumitomo Machinery Co. The program is written in English (CŌBŌL).

\section{RESULTS}

The results of this study are shown as dendrograms in Fig. 1 to 3 . The data for the original "strains $x$ characters" matrix have been deposited with the World Data Center for Microorganisms, Brisbane, Australia.

The dendrograms show the following results.
TB complex. Among the slowly growing mycobacteria studied, $M$. tuberculosis and $M$. bovis were differentiated most distinctly from the other species. These two were connected to the others at the $85 \%$ level.

Strains O5001 and O5002 of M. tuberculosis were connected to each other at the $100 \%$ level, and these were connected to strain E7193 of $M$. tuberculosis at the 99\% level. Strains O6001 and 06002 of $M$. bovis were connected to each other at $99 \%$ level. $M$. tuberculosis and $M$. bovis were connected to each other at the $97 \%$ level. Therefore, these two species form a compact cluster, referred to as the "TB complex."

Groups I, II, and III. The organisms that belong to groups I, II, and III of Runyon (23) were joined at the $91 \%$ level. Within this large group, $M$. kansasii, $M$. marinum, $M$. gastri, and $M$. shimoidei were regarded as distinct species as they were clearly differentiated from each other and from the remaining species, 
TABLE 2. Characters useful in differentiating between slowly and rapidly growing mycobacteria Genus Mycobacterium

\begin{tabular}{|c|c|c|}
\hline & & \\
\hline Distinguishing characters $^{a}$ & $\begin{array}{c}\text { Slowly } \\
\text { growing } \\
\text { mycobacte- } \\
\text { ria (A) } \\
\text { (subgenus } \\
\text { Mycobacte- } \\
\text { rium) }\end{array}$ & $\begin{array}{c}\text { Rapidly } \\
\text { growing } \\
\text { mycobacte- } \\
\text { ria (B) } \\
\text { (subgenus } \\
\text { Mycomyco- } \\
\text { bacterium) }\end{array}$ \\
\hline
\end{tabular}

1. Tolerance to $0.2 \%$ picric acid $(30,35)$

2. Tolerance to $0.1 \% \mathrm{NaNO}_{2}$ (at 14 days) $(38,58)$

3. Growth at 3 days (35)

4. Tolerance to $5 \% \mathrm{NaCl}$ (11)

5. Succinate as $\mathrm{C}$ source $(35)^{b}$

6. Malate as $\mathrm{C}$ source $(35)^{b}$

7. Fumarate as $\mathrm{C}$ source $(35)^{b}$

8. Glutamate as $\mathrm{N}$ and $\mathrm{C}$ sources $(35,37)$

9. Trimethylene diamine as $\mathrm{N}$ and $\mathrm{C}$ sources $(35,37)$

10. Acid from mannose (35, 45)

a There are the following exceptions. Character 1: (A) $M$. simiae shows positive growth on picric acidSauton agar; (B) $M$. chelonei subsp. chelonei shows negative growth. Character 2: (A) $M$. nonchromogenicum may show positive growth on nitrite-Sauton agar. Character 3: Doubtful growth may occur according to the size of inoculation. Character 5: (A) $M$. simiae shows utilization of succinate; (B) $M$. chelonei subsp. chelonei lacks utilization. Character 8: (A) A few strains of $M$. intracellulare, $M$. scrofulaceum, $M$. gordonae, and $M$. nonchromogenicum may show utilization. Character 9: (B) $M$. thermoresistibile, $M$. chitae, $M$. chelonei subsp. chelonei, $M$. vaccae, $M$. aichiense, and $M$. agari show negative reaction.

${ }^{b}$ In the presence of ammoniacal nitrogen.

which were placed in the "AXGN group" (avium-xenopi-gordonae-nonchromogenicum group).

AGXN group. The members of this group combined into one at the $92 \%$ level. Within the group, $M$. szulgai and $M$. simiae were clearly distinct from the other organisms. The others were divided into two subgroups, the "aviumgordonae-xenopi complex" and the "nonchromogenicum complex."

Avium-gordonae-xenopi complex. This complex combined into one at the $94 \%$ level. Within the complex, $M$. gordonae was clearly distinct from the others and was regarded as a separate species. $M$. xenopi also seemed to be distinct from the others.
$M$. avium, $M$. intracellulare, and $M$. scrofulaceum (especially the former two) could not be differentiated from each other on the basis of the tests used. M.asiaticum seems to be separate from the three above-mentioned species.

Nonchromogenicum complex. This complex is composed of $M$. nonchromogenicum, $M$. terrae, $M$. novum, and $M$. triviale. These combined into one at the $95 \%$ level. Of these four, $M$. triviale was barely distinguishable from the others, but $M$. nonchromogenicum, $M$. terrae, and $M$. novum formed one cluster and could not be differentiated from each other.

"Distinguishing characters." The characters that appeared to be useful for differentiating between slowly growing mycobacterial species are shown in Table 4. The percentages of strains showing positive reactions were based not only on the strains used in the present study but also on strains previously studied in our laboratory but not included in the present study.

\section{DISCUSSION}

The results show that, among the species of slowly growing mycobacteria other than $M$. tuberculosis and $M$. bovis, the following species are distinct: $M$. kansasii, $M$. marinum, $M$.gastri, M. shimoidei, M. szulgai, M. simiae, and $M$. gordonae. $M$. asiaticum and $M$. xenopi are regarded as probably distinct species.

$M$. avium, $M$. intracellulare, and $M$. scrofulaceum were not clearly separated from each other by the tests employed. The majority of the strains of $M$. intracellulare, the strains of $M$. avium, and some of the strains of $M$. scrofulaceum were combined into one cluster at the $97 \%$ level, and the majority of the strains of $M$. scrofulaceum were connected to this cluster at the $95 \%$ level.

Distinguishing characters between the strains of $M$. intracellulare which failed to grow at $45^{\circ} \mathrm{C}$ and the strains of $M$. scrofulaceum were only two: pigmentation of colonies in the dark and catalase activity (Table 4).

$M$. scrofulaceum strains usually did not utilize butanols as carbon sources, and $M$. intracellulare strains that failed to grow at $45^{\circ} \mathrm{C}$ also did not utilize butanols (47), although $M$. intracellulare strains that were able to grow at $45^{\circ} \mathrm{C}$ utilized butanols. The utilization of butanols is not a distinguishing character between these two species. Their amidase patterns were also not distinctive, as some strains of $M$. intracellulare showed urease, nicotinamidase, and pyrazinamidase activities, as did some strains of $M$. scrofulaceum. Strains of $M$. intracellulare usually showed nicotinamidase and pyrazinam- 
TABLE 3. List of characters determined on the strains used in this study ${ }^{a}$

\begin{tabular}{|c|c|}
\hline 1. Strong acid-fastness (35) & 45. Growth at $45^{\circ} \mathrm{C}(35)$ \\
\hline 2. Weak acid-fastness (39) & 46. Growth at $52^{\circ} \mathrm{C}(35)$ \\
\hline 3. Presence of rod form (35) & 47. Glucose (dextrose) as C source $(35,59)$ \\
\hline 4. Cord (35) & 48. D-Mannose as C source (35) \\
\hline 5. Fragmenting mycelium (39) & 49. Sucrose as C source $(35,59)$ \\
\hline 6. Permanent mycelium (39) & 50. $n$-Propanol as C source (34) \\
\hline 7. Rough colonies (35) & 51. $n$-Butanol as $\mathrm{C}$ source (47) \\
\hline 8. Pigmented colonies in dark (35) & 52. iso-Butanol as C source (47) \\
\hline 9. Photochromogenicity (35) & 53. Propylene glycol as C source (34) \\
\hline 10. Growth after 3 days $(35)$ & 54. D-Galactose as C source (35) \\
\hline 11. Tolerance to $0.1 \%$ nitrite (Sauton agar) $(38,58)$ & 55. L-Arabinose as $\mathrm{C}$ source (35) \\
\hline 12. Tolerance to $0.2 \%$ picric acid (Sauton agar) (30) & 56. D-Xylose as C source (35) \\
\hline 13. Resistance to rifampin $(25 \mu \mathrm{g} / \mathrm{ml})(43)$ & 57. L-Rhamnose as C source (35) \\
\hline $\begin{array}{l}\text { 14. Tolerance to } 0.2 \% \text { sodium } p \text {-aminosalicylate } \\
\text { (PAS) (32) }\end{array}$ & $\begin{array}{l}\text { 58. Trehalose as C source (35) } \\
\text { 59. Inositol as C source ( } 35)\end{array}$ \\
\hline 15. Tolerance to $125 \mu \mathrm{g}$ of $\mathrm{NH}_{2} \mathrm{OH} . \mathrm{HCl}$ per ml (31) & 60. Mannitol as $\mathrm{C}$ source $(35)$ \\
\hline 16. Tolerance to $250 \mu \mathrm{g}$ of $\mathrm{NH}_{2} \mathrm{OH}$. HCl per ml (31) & 61. Sorbitol as C source (35) \\
\hline 17. Tolerance to $500 \mu \mathrm{g}$ of $\mathrm{NH}_{2} \mathrm{OH}$. $\mathrm{HCl}$ per $\mathrm{ml}(31)$ & 62. Acetate as $\mathrm{C}$ source $(35,59)$ \\
\hline $\begin{array}{l}\text { 18. Resistance to } 10 \mu \mathrm{g} \text { of thiophene-2-carboxylic } \\
\text { acid hydrazide (TCH) per ml (4) }\end{array}$ & $\begin{array}{l}\text { 63. Citrate as C source, }(35,59) \\
64 \text {. Succinate as C source }(35,59)\end{array}$ \\
\hline $\begin{array}{l}\text { 19. Tolerance to } 0.5 \mathrm{mg} \text { of sodium salicylate per } \mathrm{ml} \\
\text { (28) }\end{array}$ & $\begin{array}{l}\text { 65. Malate as C source }(35,59) \\
66 \text {. Pyruvate as C source }(35,59)\end{array}$ \\
\hline $\begin{array}{l}\text { 20. Tolerance to } 0.5 \mathrm{mg} \text { of } p \text {-nitrobenzoic acid (PNB) } \\
\text { per } \mathrm{ml}(55)\end{array}$ & $\begin{array}{l}\text { 67. Benzoate as C source }(35) \\
68 \text {. Malonate as C source }(35,59)\end{array}$ \\
\hline 21. Niacin (production of nicotinic acid) (12) & 69. Fumarate as $\mathrm{C}$ source $(35,59)$ \\
\hline 22. Tween hydrolysis (at 7 days) (65) & 70. Acid from glucose (dextrose) (35) \\
\hline 23. Tween hydrolysis (at 14 days) (65) & 71. Acid from D-mannose (35) \\
\hline $\begin{array}{l}\text { 24. } \alpha \text {-Esterase }(10,48) \\
25 . \beta \text {-Esterase }(10,48)\end{array}$ & $\begin{array}{l}\text { 72. Glucose (dextrose) as } \mathrm{C} \text { source (glutamate-N) } \\
(57)\end{array}$ \\
\hline 26. Acid phosphatase (simple method, 3 h) (49) & 73. Acetate as $\mathrm{C}$ source (glutamate-N) (57) \\
\hline 27. Catalase (semiquantitative) (13) & 74. Succinate as $\mathrm{C}$ source (glutamate-N) (57) \\
\hline 28. $\beta$-Galactosidase (44) & 75. Pyruvate as C source (glutamate-N) (57) \\
\hline 29. Nitrate reduction $(60)$ & 76. Growth on Sauton agar (35) \\
\hline 30. Three-day arylsulfatase (17) & 77. L-Glutamate as $\mathrm{C}$ and $\mathrm{N}$ sources $(35,37)$ \\
\hline 31. Two-week arylsulfatase (17) & 78. L-Serine as $C$ and $N$ sources $(35,37)$ \\
\hline $\begin{array}{l}\text { 32. Salicylate degradation (32) } \\
\text { 33. PAS degradation }(32)\end{array}$ & $\begin{array}{l}\text { 79. D-Glucosamine hydrochloride as } \mathrm{C} \text { and } \mathrm{N} \\
\text { sources }(35,37)\end{array}$ \\
\hline 34. Acetamidase (5) & 80. Acetamide as $\mathrm{C}$ and $\mathrm{N}$ sources $(35,37)$ \\
\hline 35. Benzamidase (5) & 81. Benzamide as $\mathrm{C}$ and $\mathrm{N}$ sources $(35,37)$ \\
\hline 36. Urease (5) & 82. Monoethanolamine as $\mathrm{C}$ and $\mathrm{N}$ sources $(35,37)$ \\
\hline 37. Isonicotinamidase (5) & 83. Trimethylene diamine as $\mathrm{C}$ and $\mathrm{N}$ sources $(35$, \\
\hline 38. Nicotinamidase (5) & $37)$ \\
\hline 39. Pyrazinamidase (5) & 84. Benzamide as $\mathrm{N}$ source (54) \\
\hline 40. Salicylamidase (5) & 85. Nicotinamide as $\mathrm{N}$ source (54) \\
\hline 41. Allantoinase (5) & 86. Nitrate as $N$ source $(54)$ \\
\hline 42. Succinamidase (5) & 87. Nitrite as $\mathrm{N}$ source (53) \\
\hline 43. Growth at $28^{\circ} \mathrm{C}(35)$ & 88. Resistance to ethambutol $(5 \mu \mathrm{g} / \mathrm{ml})(38,40)$ \\
\hline 44. Growth at $37^{\circ} \mathrm{C}(35)$ & \\
\hline
\end{tabular}

${ }^{a}$ Unless noted otherwise, the tolerance and resistance tests were carried out in Ogawa egg medium (35). Amidase tests (no. 34 to 42 ) were carried out after incubation of the test organism with amide at $37^{\circ} \mathrm{C}$ for 24 h. Unless noted otherwise, utilization of carbohydrates was tested in the presence of ammoniacal nitrogen (no. 47 to no. 69) $(34,35,47,51)$.

idase activities, but a few strains of $M$. scrofulaceum also showed these amidase activities.

The results obtained here show that $M$. avium, $M$. intracellulare, and $M$. scrofulaceum should be combined into a single species, for which the name $M$. avium has priority. This suggestion agrees with the results of the numerical taxonomy study carried out previously by Tsukamura, Mizuno, and Tsukamura (51) and with the results of lipid analysis by Marks, Jenkins, and Schaefer (19). The finding that $M$. avium and $M$. intracellulare are not clearly distinguishable from each other was also obtained by Wayne (62) and by Meissner et al. (21).

In addition, the results of the present study 
M-ralue (\%)

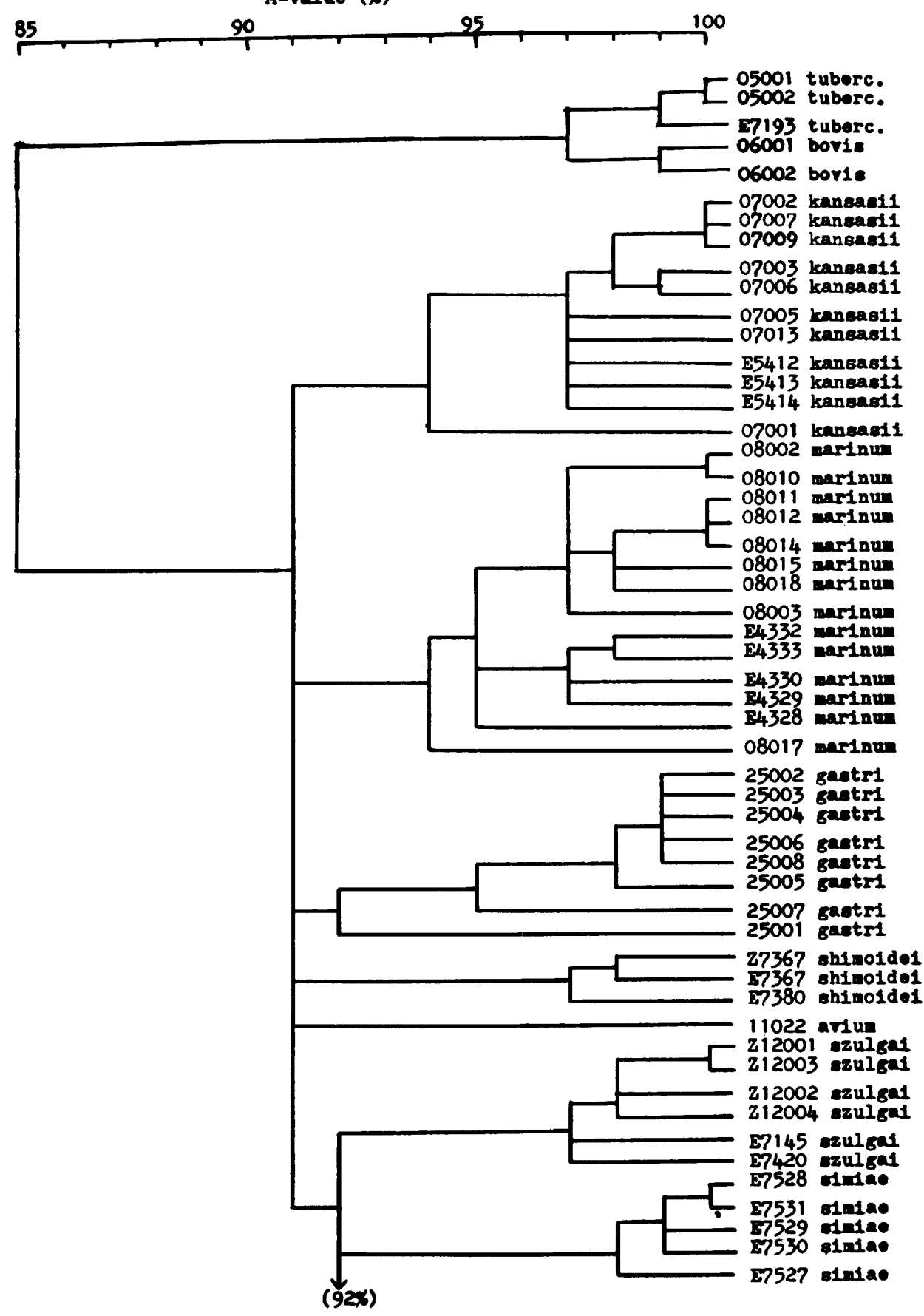

FIG. 1. Dendrogram showing the relationship of the 138 strains of slowly growing mycobacteria studied. 
M-value (x)

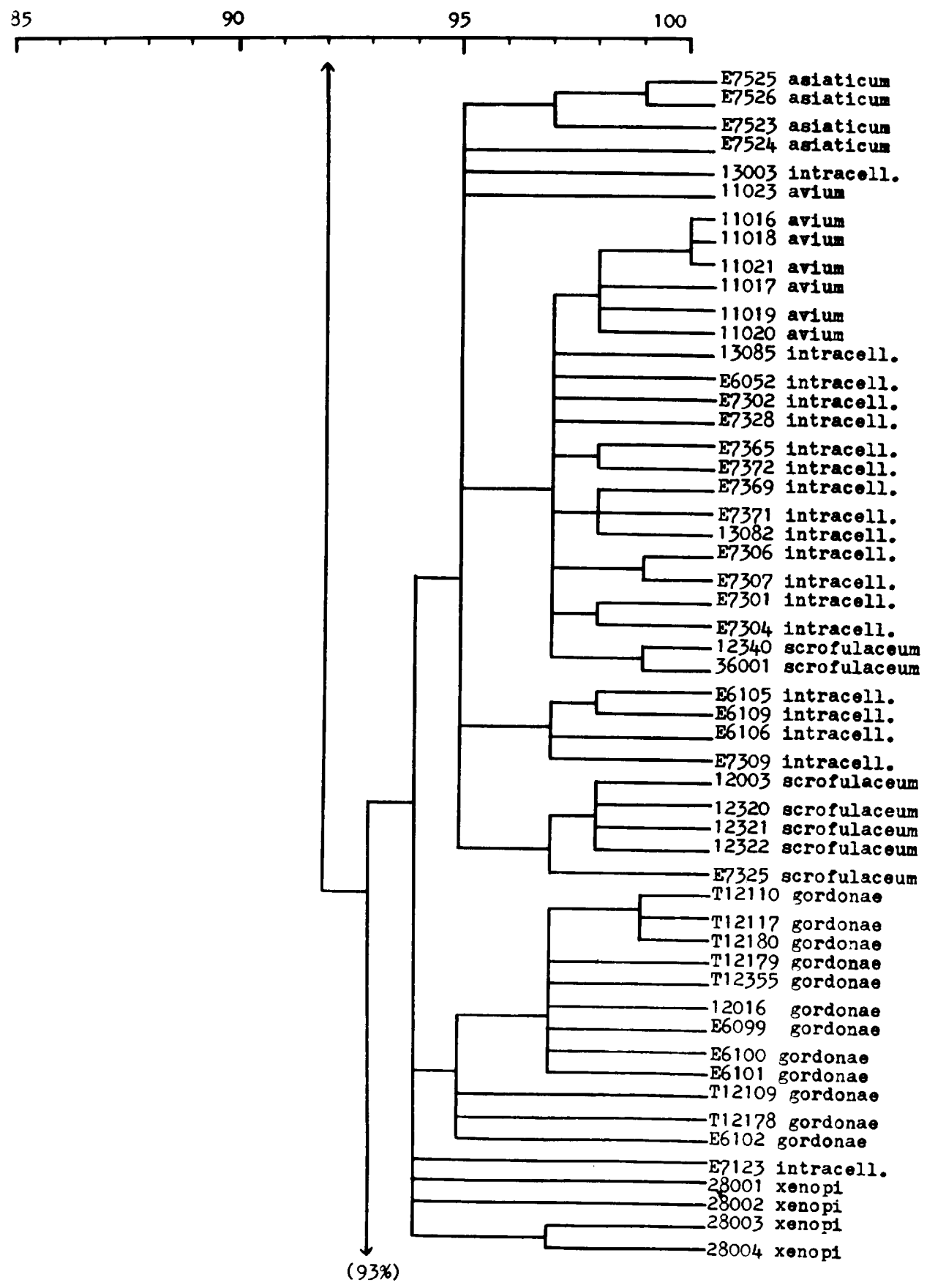

FIG. 2. Dendrogram showing the relationship of the 138 strains of slowly growing mycobacteria studied. 
TABLE 4. Characters useful for differentiating between slowly growing mycobacteria

\begin{tabular}{|c|c|c|c|c|c|c|c|c|c|c|c|c|c|c|c|c|c|c|c|c|}
\hline \multirow{3}{*}{ Character } & \multicolumn{20}{|c|}{ No. of strains showing positive reaction (\%) } \\
\hline & 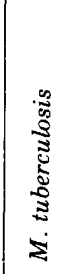 & 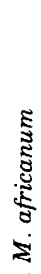 & 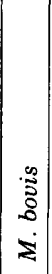 & 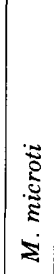 & 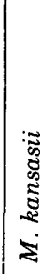 & 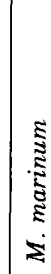 & 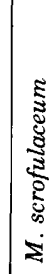 & 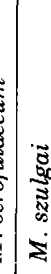 & 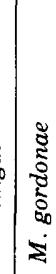 & 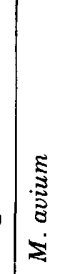 & 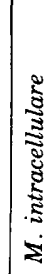 & 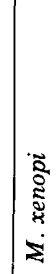 & 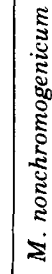 & 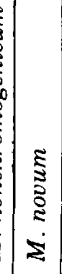 & 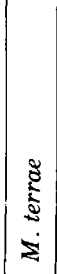 & 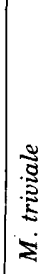 & 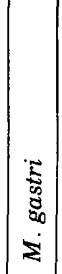 & 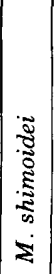 & 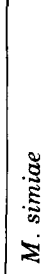 & 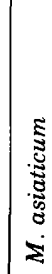 \\
\hline & $95^{a}$ & 14 & 43 & 6 & 68 & 31 & 46 & 6 & 50 & 26 & 100 & 4 & 93 & 26 & 15 & 22 & 15 & 5 & & 4 \\
\hline Rough colonies & 94 & 29 & 37 & 100 & 100 & 84 & 11 & 50 & 0 & 0 & 3 & 0 & 0 & 0 & 0 & 100 & 0 & 60 & 0 & 0 \\
\hline tation & 0 & 0 & 0 & 0 & 0 & 0 & 100 & 0100 & 0 & 0 & 0 & 75 & 0 & 0 & 0 & 0 & 0 & 0 & 0 & 0 \\
\hline $\mathbf{P}$ & 0 & 0 & 0 & 0 & 97 & 100 & & 0 & \begin{tabular}{l|l}
0 & 0
\end{tabular} & 0 & 0 & 0 & 0 & $\begin{array}{lll}0 & 0\end{array}$ & 0 & 0 & 0 & 0 & & 100 \\
\hline t $28^{\circ} \mathrm{C}$ & 13 & 14 & 18 & 67 & 100 & 100 & 100 & 0100 & $0 \quad 100$ & 85 & 97 & 0 & 100 & 100 & 100 & 100 & 100 & 100 & 100 & 100 \\
\hline rowth at $45^{\circ} \mathrm{C}$ & 0 & 0 & 0 & 0 & 0 & 0 & 4 & 4.0 & \begin{tabular}{l|l}
0 & 0
\end{tabular}$\longrightarrow \longrightarrow$ & 77 & 71 & 100 & 0 & 0 & 0 & 0 & 0 & 100 & 0 & 75 \\
\hline $0.2 \%$ PAS & 0 & 0 & 0 & 0 & $\mathbf{0}$ & 97 & 70 & & 90 & 100 & 99 & 0 & 97 & $7 \mid 100$ & 80 & 100 & 53 & 100 & 100 & 100 \\
\hline $\begin{array}{l}\text { Tolerance to } 0.125 \mathrm{mg} \text { of } \mathrm{NH}_{2} \mathrm{OH} \\
\text { per ml }\end{array}$ & 0 & 0 & 0 & 0 & 96 & 100 & 100 & $0 \quad 100$ & \begin{tabular}{l|l}
0 & 100
\end{tabular} & 100 & 100 & 50 & 100 & 100 & 100 & 100 & 87 & 20 & 100 & 100 \\
\hline $\begin{array}{l}\text { Tolerance to } 0.25 \mathrm{mg} \text { of } \mathrm{NH}_{2} \mathrm{OH} \\
\text { per } \mathrm{ml}\end{array}$ & 0 & 0 & 0 & 0 & 22 & 100 & 100 & 0 & 90 & 92 & 100 & 25 & 100 & 100 & 100 & 100 & 60 & 0 & 100 & 100 \\
\hline $\begin{array}{l}\text { Tolerance to } 0.5 \mathrm{mg} \text { of } \mathrm{NH}_{2} \mathrm{OH} \text { per } \\
\mathrm{ml}\end{array}$ & 0 & 0 & 0 & 0 & 0 & 97 & 87 & 100 & 56 & 62 & 97 & 0 & 100 & 100 & 100 & 95 & 0 & 0 & 100 & 100 \\
\hline th on Sauton agar & 0 & 0 & 0 & 0 & 100 & 100 & 100 & 100 & 100 & 100 & 100 & 100 & 94 & 0 & 73 & 100 & 100 & & 100 & 100 \\
\hline & 0 & 0 & 0 & 0 & 0 & 0 & 0 & 0 & $\begin{array}{l}0 \\
0\end{array}$ & 0 & 0 & 0 & 0 & 0 & 0 & 0 & 0 & & 100 & ) 0 \\
\hline & 0 & 57 & 89 & 100 & 100 & 100 & 85 & 5100 & 84 & 8 & 71 & 100 & 80 & 8 & 93 & 100 & 100 & 0 & 100 & ) \\
\hline$\mu \mathrm{g} / \mathrm{ml})$ & 86 & 0 & 9 & 0 & 100 & 100 & 100 & \begin{tabular}{l|l}
0 & 100
\end{tabular} & \begin{tabular}{l|l}
0 & 100
\end{tabular} & 100 & 100 & 100 & 100 & 100 & 100 & 100 & 100 & 100 & 100 & 100 \\
\hline & 0 & 0 & 0 & 0 & 91 & 90 & 100 & 0 & 100 & 100 & 100 & 100 & 100 & 100 & 100 & 100 & 100 & 100 & 100 & 100 \\
\hline & $-{ }^{b}$ & 0 & 0 & 0 & 0 & 55 & 78 & $\begin{array}{l}3 \\
3\end{array}$ & \begin{tabular}{l|l}
0 & 68
\end{tabular} & $\begin{array}{l}35 \\
\end{array}$ & 96 & 100 & 100 & 100 & 100 & 41 & 0 & 100 & 100 & 100 \\
\hline $\begin{array}{l}\text { Resistance to ethambutol }(5 \mu \mathrm{g} / \\
\mathrm{ml})\end{array}$ & $-{ }^{b}$ & 0 & 0 & 0 & 24 & 26 & 100 & 3 & 0 & 100 & 100 & 100 & 0 & 0 & 0 & 0 & 0 & 0 & 100 & 100 \\
\hline & 89 & 79 & 9 & 100 & 0 & 42 & 0 & 0 & 0 & 0 & 0 & 0 & & 0 & 0 & 0 & 0 & 0 & $|100|$ & 0 \\
\hline & 0 & 0 & 0 & 0 & 78 & 23 & 0 & ) & 80 & 0 & 0 & 0 & 100 & 100 & 100 & 100 & 93 & 0 & 0 & \\
\hline & 0 & 0 & 0 & 0 & 98 & 48 & 11 & 50 & 96 & 0 & 2 & 0 & 100 & 100 & 100 & 100 & 100 & 100 & 0 & 0 \\
\hline$(5 \mathrm{~mm})$ & 0 & 0 & 0 & 0 & 98 & 5 & 85 & 100 & 96 & 0 & 4 & 0 & 100 & 100 & 87 & 100 & 0 & 0 & 100 & 100 \\
\hline & 100 & 86 & 100 & 100 & 6 & 0 & 100 & 83 & 14 & 100 & 97 & 100 & 11 & 8 & 7 & 14 & 0 & 40 & 100 & \\
\hline & 100 & 71 & 100 & 100 & 54 & 48 & 100 & 67 & 52 & 100 & 97 & 100 & 84 & 92 & 87 & 100 & 0 & 20 & 100 & 100 \\
\hline & 0 & 0 & 0 & 0 & 0 & 0 & 0 & 0 & 0 & 0 & 0 & 0 & 74 & 100 & 73 & 45 & 0 & 0 & 0 & 0 \\
\hline & 0 & 0 & 0 & 0 & 97 & 90 & 78 & 100 & 24 & 88 & 90 & 0 & 100 & 100 & 100 & 100 & 93 & 100 & 0 & 100 \\
\hline & 100 & 0 & 37 & 0 & 100 & 16 & 0 & 1 & & 0 & 1 & 0 & 29 & 8 & 7 & 100 & 53 & 0 & & 0 \\
\hline & 100 & 86 & 93 & 100 & 100 & 100 & 48 & 100 & 54 & 0 & 4 & 0 & 0 & 0 & 0 & 9 & 100 & 0 & 100 & 0 \\
\hline & 96 & 43 & 18 & 100 & 100 & 55 & 7 & 0 & 0 & 35 & 67 & 50 & 48 & 0 & 0 & 0 & 100 & 40 & 0 & 25 \\
\hline & 80 & 21 & 0 & 100 & 0 & 29 & 7 & 0 & 0 & 31 & 67 & 50 & 49 & 0 & 0 & 0 & 0 & 40 & 0 & 25 \\
\hline & 21 & 7 & 23 & 50 & 15 & 71 & 0 & 0 & ) & 0 & 0 & 0 & 0 & 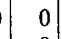 & 0 & 5 & 0 & 0 & 60 & \\
\hline $\begin{array}{l}\text { Glucose as C source (glutamate- } \\
\mathrm{N} \text { ) }\end{array}$ & 0 & 0 & 51 & 33 & 100 & 100 & 91 & 0 & 90 & 15 & 89 & 0 & 0 & 0 & 0 & 14 & 100 & 0 & 100 & 100 \\
\hline $\begin{array}{l}\text { Acetate as C source (glutamate- } \\
\mathrm{N} \text { ) }\end{array}$ & 0 & 14 & 58 & 33 & 100 & 100 & 96 & 100 & 90 & 88 & 88 & 100 & 92 & 15 & 13 & 77 & $100 \mid$ & 0 & 100 & 100 \\
\hline $\begin{array}{l}\text { Succinate as C source (glutamate- } \\
\text { N) }\end{array}$ & 0 & 0 & 44 & 17 & 57 & 82 & 39 & 0 & 24 & 0 & 56 & 0 & 0 & 0 & 0 & 0 & 13 & 0 & 100 & 100 \\
\hline $\begin{array}{l}\text { Pyruvate as C source (glutamate- } \\
\text { N) }\end{array}$ & 16 & 7 & 83 & 33 & 100 & 100 & 100 & 83 & 88 & 92 & 92 & 100 & 63 & 0 & 7 & 41 & 100 & 100 & 100 & 100 \\
\hline & 0 & 0 & 0 & 0 & 98 & 71 & 70 & 0 & 54 & 0 & 4 & 0 & 0 & 0 & 0 & 0 & 67 & 0 & 0 & 25 \\
\hline & 0 & 0 & 0 & 0 & 15 & 83 & 76 & 0 & 80 & 58 & 58 & 0 & 26 & 0 & 47 & 5 & 60 & 0 & 100 & 75 \\
\hline & 0 & 0 & 0 & 0 & 12 & 13 & 15 & 0 & 0 & 27 & 69 & 0 & 42 & 15 & 53 & 14 & 93 & 0 & 0 & 50 \\
\hline & 0 & 0 & 0 & 0 & 12 & 6 & 9 & 0 & 76 & 27 & 64 & 0 & 29 & 0 & 40 & 5 & 93 & 0 & 0 & 25 \\
\hline & 0 & 0 & 0 & 0 & 75 & 100 & 98 & 100 & 98 & 69 & 92 & 100 & 75 & 15 & 33 & 82 & 100 & 0 & 100 & 100 \\
\hline & 0 & 0 & 0 & 0 & 0 & 0 & 0 & 0 & 0 & 0 & 0 & 0 & 0 & 0 & 0 & 0 & 0 & 0 & 80 & 0 \\
\hline & 0 & 0 & 0 & 0 & 100 & 93 & 96 & 100 & 98 & 65 & 90 & 100 & 61 & 0 & 13 & 91 & 100 & 0 & 100 & 75 \\
\hline Tolerance to $0.1 \%$ nitrite & 0 & 0 & 0 & 0 & 0 & 0 & 0 & 0 & 0 & 0 & 0 & 0 & 60 & 0 & 80 & 41 & 0 & 0 & 0 & 0 \\
\hline
\end{tabular}

${ }^{a}$ Number of strains tested.

${ }^{b}$ Not counted, as patients treated with these agents may excrete resistant organisms. 


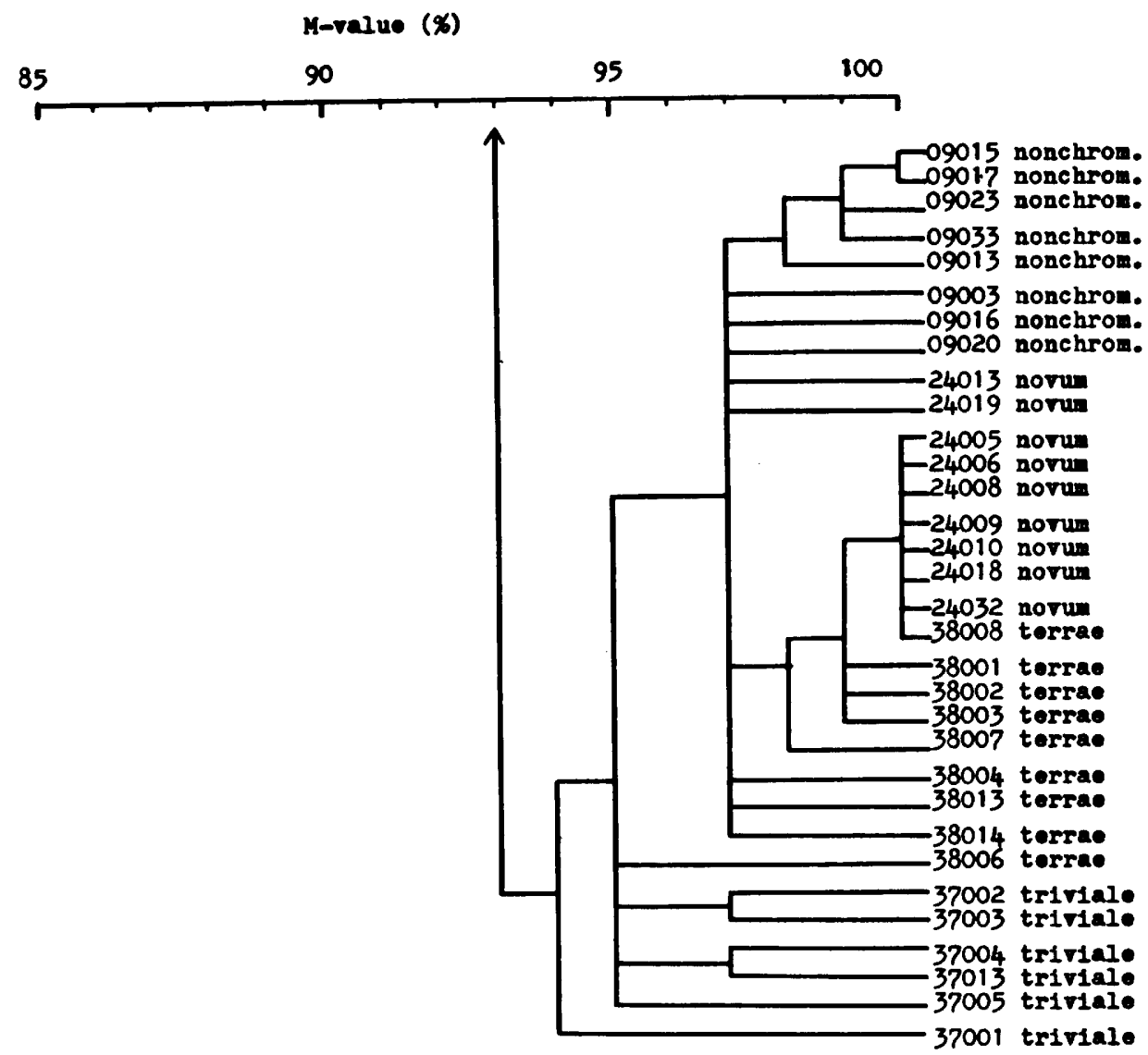

FIG. 3. Dendrogram showing the relationship of the 138 strains of slowly growing mycobacteria studied.

showed that $M$. nonchromogenicum, $M$. terrae, and $M$. novum cannot be differentiated from each other and that $M$. triviale is slightly different from these three. Although this finding is similar to that of Kubica, Silcox, and Hall (15), it is, in part, contradictory to that of the International Working Group for Mycobacterial Taxonomy (IWGMT) (21). The IWGMT reported that $M$. nonchromogenicum and $M$. terrae resemble each other but are distinguishable from each other. Cooperative studies benefit from the performance of many tests but have the fault that small differences may be accentuated in importance by the performance of similar tests by several workers. The present study indicates that $M$. nonchromogenicum and $M$. terrae belong to one species rather than to different species. $M$. nonchromogenicum, $M$. terrae, and $M$. novum should be combined into a single species, for which the name $M$. nonchromogenicum has priority. $M$. terrae and $M$. novum thus are subjective synonyms of $M$. non- chromogenicum. M. triviale may be regarded as a different species.

Finally, it is noteworthy that $M$. gastri, $M$. shimoidei, $M$. szulgai, and $M$. simiae occupy a distinct position and that $M$. asiaticum is closely related to $M$. avium.

\section{ACKNOWLEDGMENTS}

I thank S. Uchida, Sumitomo Machinery Co., for his kind help in the use of computers, and S. Mizuno, $\mathrm{H}$. Murata, and T. Oshima for their technical assistance.

\section{REPRINT REQUESTS}

Address reprint requests to: Dr. M. Tsukamura, The National Chubu Hospital, Obu, Aichi, Japan 474.

\section{LITERATURE CITED}

1. Aronson, J. D. 1926. Spontaneous tuberculosis in soft water fish. J. Infect. Dis. 39:315-320.

2. Bogdanescu, V., and R. Racotta. 1967. Identification of mycobacteria by overall similarity analysis. J. Gen. Microbiol. 48:111-126.

3. Bojalil, L. F., J. Cerbón, and A. Trujillo. 1962. Adansonian classification of mycobacteria. J. Gen. Microbiol. 28:333-346. 
4. Bönicke, R. 1958. Ueber die tuberkulostatische Wirksamkeit pentaheterocyclischer Carbonsäurehydrazide. Z. Hyg. 145:263-275.

5. Bönicke, R. 1962 . L'identification des mycobactéries à l'aide de méthodes biochimiques. Bull. Union Int. Tuberc. 32:13-76.

6. Breed, R. S., E. G. D. Murray, and N. R. Smith. 1957. Bergey's manual of determinative bacteriology, 7 th ed., p. 702-703. The Williams \& Wilkins Co., Baltimore.

7. Buchanan, R. E., J. G. Holt, and E. F. Lessel, Jr. (ed.). 1966. Index Bergeyana. The Williams \& Wilkins Co., Baltimore.

8. Chester, F. D. 1901. A manual of determinative bacteriology, p. 356. Macmillan Publishing Co., New York.

9. Hauduroy, P. 1955. Derniers aspects du monde des mycobactéries, p. 73. Masson et Cie, Paris.

10. Käppler, W. 1965. Acetyl-Naphthylamin-Esterasen-Aktivität von Mykobakterien. Beitr. Klin. Tuberk. Spezifischen Tuberk. Forsch. 130:1-4.

11. Kestle, D. G., V. D. Abbott, and G. P. Kubica. 1967 Differential identification of mycobacteria. II Subgroups of Groups II and III (Runyon) with different clinical significance. Am. Rev. Respir, Dis. 95: 1041-1052.

12. Konno, K. 1962 . Biochemical classification of mycobacteria. Kekkaku 37:315-324.

13. Kubica, G. P., W. D. Jones, Jr., V. D. Abbott, R. E. Beam, J. O. Kilburn, and J. C. Cater, Jr. 1966. Differential identification of mycobacteria. Tests on catalase activity. Am. Rev. Respir. Dis. 94:400-405.

14. Kubica, G. P., and V. A. Silcox. 1973. Numerical taxonomic analysis of some slowly growing mycobacteria using hypothetical median strain patterns. J. Gen. Microbiol. 74:149-158.

15. Kubica, G. P., V. A. Silcox, and E. Hall. 1973. Numerical taxonomy of selected slowly growing mycobacteria. J, Gen. Microbiol. 74:159-167.

16. Kubica, G. P., V. A. Silcox, J. O. Kilburn, R. W. Smithwick, R. E. Beam, W. D. Jones, and K. D. Stottmeier. 1970. Differential identification of mycobacteria. VI. Mycobacterium triviale Kubica sp. nov. Int. J. Syst. Bacteriol. 20:161-174.

17. Kubica, G. P., and A. L. Vestal. 1961. The arylsulfatase activity of acid-fast bacilli. Investigation of activity of stock cultures of acid-fast bacilli. Am. Rev. Respir. Dis. 83:728-732.

18. Lehmann, K. B., and R. O. Neumann. 1896. Atlas und Grundriss der Bakteriologie und Lehrbuch der speziellen bakteriologischen Diagnostik. Teil II, p. 363 (cited from Index Bergeyana [7]).

19. Marks, J., P. A. Jenkins, and W. B. Schaefer. 1971. Thin-layer chromatography of mycobacterial lipids as an aid to classification: technical improvements: $\boldsymbol{M y}$ cobacterium avium, $M$. intracellulare (Battey bacilli). Tubercle 52:219-225.

20. Marks, J., P. A. Jenkins, and M. Tsukamura. 1972. Mycobacterium szulgai-a new pathogen. Tubercle 53:210-214.

21. Meissner, G., K. H. Schröder, G. E. Amadis, W. Anz, S Chaparas, H. B. W. Engel, P. A. Jenkins, W. Käppler, H. H. Kleeberg, E. Kubala, M. Kubin, D. Lauterbach, A. Lind, M. Magnusson, Z. Mikova, S. R. Pattyn, W. B. Schaefer, J. L. Stanford, M. Tsukamura, L. G. Wayne, I. Willers, and E. Wolinsky. 1974. A co-operative numerical analysis of nonscotoand nonphotochromogenic slowly growing mycobacteria. J. Gen. Microbiol. 83:207-235.

22. Prissick, F. H., and A. M. Masson. 1956. Cervical lymphadenitis in children caused by chromogenic mycobacteria. Can. Med. Assoc. J. 75:798-803.

23. Runyon, E. H. 1959. Anonymous mycobacteria in pul- monary disease. Med. Clin. North Am. 43:273-290.

24. Runyon, E. H. 1967. Mycobacterium intracellulare. Am Rev. Respir. Dis. 95:861-865.

25. Schwabacher, H. 1959. A strain of Mycobacterium isolated from skin lesions of a cold-blooded animal, Xenopus laevis, and its relation to atypical acid-fast bacilli occurring in man. J. Hyg. 57:57-67.

26. Sokal, R. R., and P. H. A. Sneath. 1963. Principles of numerical taxonomy, p. 1-359. W. H. Freeman, San Francisco.

27. Suzanne, M., and G. Penso. 1953. Sulla identità specifica del cosidetto "Ceppo Chauvirè", Mycobacterium marianum n. sp. Riassunto delle Communicazione del VI. Congr. Int. Microbiol. (Roma) 2:655-656.

28. Tsukamura, M. 1962. Differentiation of Mycobacterium tuberculosis from other mycobacteria by sodium salicylate susceptibility. Am. Rev. Respir. Dis. 86:81-83.

29. Tsukamura, M. 1965. A group of mycobacteria from soil sources resembling nonphotochromogens (Group 3). A description of Mycobacterium nonchromogenicum. Med. Biol. (Tokyo) 71:110-113.

30. Tsukamura, M. 1965. Differentiation of mycobacteria by picric acid tolerance. Am. Rev. Respir. Dis. 92:491-492.

31. Tsukamura, M. 1965. Differentiation of mycobacteria by susceptibility to hydroxylamine and 8-azaguanine. J. Bacteriol. 90:556-557.

32. Tsukamura, M. 1965 . Salicylate degradation test for differentiation of Mycobacterium fortuitum from other mycobacteria. J. Gen. Microbiol. 41:317-320.

33. Tsukamura, M. 1966. Adansonian classification of mycobacteria. J. Gen. Microbiol. 45:253-273.

34. Tsukamura, M. 1966 . Utilization of glycols and certain other carbohydrates by mycobacteria as sole carbon source. Am. Rev. Respir. Dis. 94:796-798.

35. Tsukamura, M. 1967. Identification of mycobacteria. Tubercle 48:311-338.

36. Tsukamura, M. 1967. Two types of slowly growing, nonphotochromogenic mycobacteria obtained from soil by the mouse passage method: Mycobacterium terrae and Mycobacterium novum. Jpn. J. Microbiol. 11:163-172.

37. Tsukamura, M. 1967. Differentiation of mycobacteria by utilization of nitrogen compounds as simultaneous nitrogen and carbon sources. Am. Rev. Respir. Dis. 95:307-310.

38. Tsukamura, M. 1969. Identification of Group II scotochromogens and Group III nonphotochromogens of mycobacteria. Tubercle 50:51-60.

39. Tsukamura, M. 1969. Numerical taxonomy of the genus Nocardia. J. Gen. Microbiol. 56:265-287.

40. Tsukamura, M. 1970. Differentiation between pathogenic and nonpathogenic mycobacteria of Group II and Group III by susceptibility to ethambutol. Kekkaku 45:237-240.

41. Tsukamura, M. 1971. Relationship between Mycobacterium nonchromogenicum, Mycobacterium terrae, $M y$ cobacterium novum and subgroup "V" (Mycobacterium triviale). Jpn. J. Microbiol. 15:229-236.

42. Tsukamura, M. 1971. Some considerations on classification of mycobacteria. Definition of bacterial species by introduction of the concept of "hypothetical median or mean organism." Jpn. J. Tuberc. Chest Dis. 17:18-30.

43. Tsukamura, M. 1972. Susceptibility of Mycobacterium intracellulare to rifampicin. A trial of ecological observation. Jpn. J. Microbiol. 16:444-446.

44. Tsukamura, M. 1974. Differentiation of the Mycobacterium' rhodochrous-group from nocardiae by $\beta$-galactosidase activity. J. Gen. Microbiol. 80:553-555.

45. Tsukamura, M. 1975. Numerical analysis of the relationship between Mycobacterium, Rhodochrous 
group, and Nocardia by use of hypothetical median organisms. Int. J. Syst. Bacteriol. 25:329-335.

46. Tsukamura, M., and S. Mizuno. 1968. "Hypothetical mean organisms" of mycobacteria. A study of classification of mycobacteria. Jpn. J. Microbiol. 12:371-384.

47. Tsukamura, M., and S. Mizuno. 1971. Differentiation of Mycobacterium avium and Mycobacterium intracellulare by utilization of butanols as carbon source. Kekkaku 46:197-202.

48. Tsukamura, M., S. Mizuno, and H. Murata. 1972. Acetyl-naphthylamine esterase activity of mycobacteria. Kekkaku 47:41-45.

49. Tsukamura, M., S. Mizuno, H. Murata, and T. Oshima. 1974. Acid phosphatase activity of mycobacteria. Iryo (Tokyo) 28:275-279.

50. Tsukamura, M., S. Mizuno, and S. Tsukamura. 1967. Numerical classification of atypical mycobacteria. Jpn. J. Microbiol. 11:233-241.

51. Tsukamura, M., S. Mizuno, and S. Tsukamura. 1969. Numerical classification of slowly growing mycobacteria. Am. Rev. Respir. Dis. 99:299-303.

52. Tsukamura, M., H. Shimoide, and W. B. Schaefer. 1975. A possible new pathogen of Group III mycobacteria. J. Gen. Microbiol. 88:377-380.

53. Tsukamura, M., and J. Tsukamura. 1965. Differentiation of mycobacteria by utilization of nitrite as sole nitrogen source. J. Bacteriol. 89:1442.

54. Tsukamura, M., and J. Tsukamura. 1966. Differentiation of mycobacteria by utilization of amides and amino acids as sole nitrogen sources. Am. Rev. Respir. Dis. 94:104-107.

55. Tsukamura, M., and S. Tsukamura. 1964. Differentiation of Mycobacterium tuberculosis and Mycobacterium bovis by $\mathrm{p}$-nitrobenzoic acid susceptibility. Tubercle 45:64-65.

56. Tsukamura, M., and S. Tsukamura. 1966. Classification and identification of slowly growing mycobacteria. I. Adansonian classification of slowly growing mycobacteria by forty-three characters. Jpn. J. Bacteriol. 21:217-221.

57. Tsukamura, M., and S. Tsukamura. 1967. A comparative study of carbon source requirements of Mycobacterium avium, Group II scotochromogens, Group III nonphotochromogens, and Mycobacterium terrae in the presence of glutamate-nitrogen. Am. Rev. Respir. Dis. 96:512-516.

58. Tsukamura, M., and S. Tsukamura. 1968. Differentiation of mycobacteria by susceptibility to nitrite and propylene glycol. Am. Rev. Respir. Dis. 98:505-506.

59. Tsukamura, S., S. Mizuno, and M. Tsukamura. 1967. Utilization for growth of ten carbohydrates by slowly growing mycobacteria in the presence of ammoniacal nitrogen and trimethylene diamine nitrogen. Am. Rev. Respir. Dis. 96:529-531.

60. Virtanen, S. 1960. A study of nitrate reduction by mycobacteria. The use of the nitrate reduction test in the differentiation of mycobacteria. Acta Tuberc. Scand. Suppl. 48:1-119.

61. Wayne, L. G. 1966. Classification and identification of mycobacteria. III. Species within Group III. Am. Rev. Respir. Dis. 93:919-928.

62. Wayne, L. G. 1967. Selection of characters for an Adansonian analysis of mycobacterial taxonomy. J. Bacteriol. 93:1382-1391.

63. Wayne, L. G., T. M. Dietz, C. Gernez-Rieux, P. A. Jenkins, W. Käppler, G. P. Kubica, J. B. G. Kwapinski, G. Meissner, S. R. Pattyn, E. H. Runyon, K. H. Schröder, V. A. Silcox, A. Tacquet, M. Tsukamura, and E. Wolinsky. 1971. A co-operative numerical analysis of scotochromogenic slowly growing mycobacteria. J. Gen. Microbiol. 66:255-271.

64. Wayne, L. G., J. R. Doubek, and G. A. Diaz. 1967. Classification and identification of mycobacteria. IV. Some important scotochromogens. Am. Rev. Respir. Dis. 96:88-95.

65. Wayne, L. G., J. R. Doubek, and R. L. Russell. 1964. Classification and identification of mycobacteria. I. Tests employing Tween 80 as substrate. Am. Rev. Respir. Dis. 90:588-597.

66. Weiszfeiler, J. G. 1969. Die Biologie und Variabilität des Tuberkelbakteriums und die atypischen Mycobakterien, p. 227-256. Akadémiai Kiadó, Budapest.

67. Weiszfeiler, G., V. Karasseva, and E. Karczag. 1971. A new Mycobacterium species: Mycobacterium asiaticum n. sp. Acta Microbiol. Acad. Sci. Hung. 18:247252. 